\title{
Sulphydryl Metabolism of Fungi Grown in Submerged Culture
}

\author{
By JUNE E. ROBSON AND HAZEL M. S'TOCKLEY \\ Isotope Research Division, Wantage Research Laboratories (A.E.R.E.), Wantage, Berks
}

(Received 1 July 1961)

SUMMARY

Radioactive phenyl mercuric chloride (labelled with ${ }^{203} \mathrm{Hg}$ ) was used to measure - $\mathrm{SH}$ groups in the mycelium and in the medium. Tritiated phenyl mercuric chloride was used as a quantitative cytological reagent. The changes in $-\mathrm{SH}$ concentration of the fungus were not always directly related to the changes in total $\mathrm{S}$ in Aspergillus niger, Penicillium chrysogenum 49.133, Eremothecium ashbyii and Candida albicans. A peak in -SH concentration occurred in the cells of these organisms during the early growth phase. Extracellular - SH compounds were produced by all these organisms at some time during development. Cytological studies showed differences in the distribution of $-\mathrm{SH}$ compounds in the cell wall and cytoplasm. E. ashbyii and C. albicans had a strong $-\mathrm{SH}$ reaction in the cell wall, $\boldsymbol{A}$. niger and $\boldsymbol{P}$. chrysogenum 49.133 a weak one. Sulphydryl compounds were most concentrated in areas of hyphal bud formation in $E$. ashbyii but were not concentrated at the hyphal tip.

\section{IN'TRODUCTION}

Previous studies (Robson, 1958) on the metabolism of ${ }^{35} \mathrm{SO}_{4}$ in certain fungi grown in submerged culture showed that the ${ }^{35} \mathrm{~S}$ content/mg. dry weight changed during development. Simultaneously, changes in sulphur compounds in the growth medium occurred. Chromatographic analysis of the ${ }^{35} \mathrm{~S}$ compounds in the medium revealed that ${ }^{35} \mathrm{SO}_{4}$ was rapidly metabolized into many different substances in the early stages of development. Some of these compounds disappeared as the fungus grew. This suggested that ${ }^{35} \mathrm{SO}_{4}$ was metabolized extracellularly before sulphur was incorporated into the organism. During later stages the reverse of this process seemed to occur, namely, sulphur-containing substances present in the mycelium were excreted into the medium. Cytological studies showed that ${ }^{35} \mathrm{~S}$ was present in the cell wall of the fungus and in the cytoplasm. To discover more about the metabolism of sulphur by the fungal cell, attempts were made to measure the $-\mathrm{SH}$ sulphur present in the cell and in the medium during growth with radioactive reagents. Organo-mercury compounds have been used by several authors to measure -SH groups in proteins (Hellerman, Perkins \& Clark, 1933; Olcott \& Fraenkel-Conrat, 1947; Hughes, 1950) and have been described as satisfactory specific reagents. Janke, Beran \& Schmidt (1953) showed that the reaction of phenyl mercuric compounds with fungal spores could be completely annulled with cysteine, thioglycollic (mercaptoacetic) acid and 2,3-dimercaptopropanol. Thus phenyl mercuric chloride was chosen as a suitable reagent for $-\mathrm{SH}$ groups in fungi. Phenyl mercuric chloride can be labelled with radioactive ${ }^{203} \mathrm{Hg},{ }^{14} \mathrm{C}$, or ${ }^{3} \mathrm{H}$. 
Because the $\gamma$-radiations emitted by ${ }^{203} \mathrm{Hg}$ can be measured simply with a scintillation counter, this isotope was chose $\mathrm{n}$ to label the phenyl mercuric chloride used for the estimation of total - $\mathrm{SH}$ sulphur in the fungus. Tritium was a more suitable label than ${ }^{14} \mathrm{C}$ for the phenyl mercuric chloride used to discover the distribution of - SH compounds within the cell. The position of a ${ }^{3} \mathrm{H}$ atom in a cell can be resolved by autoradiography to about $1 \mu$; the autoradiographic resolution of a ${ }^{14} \mathrm{C}$ atom is from 1 to $2 \mu$.

\section{METHODS}

Organisms. Four organisms were used, namely, Aspergillus niger and Candida albicans (from the Botany Department, The University, Exeter), Penicillium chrysogenum, 49.133 (from Glaxo Laboratories, Stoke Poges) and Eremothecium ashbyii (from Centraal-bureau voor Schimsnelcultures, Baarn).

Culture media. The fungi were grown in a medium containing glucose, $10 \cdot 0 \mathrm{~g}$; $\mathrm{K}_{2} \mathrm{HPO}_{4}, 1.5 \mathrm{~g}$.; $\mathrm{MgSO}_{4} .7 \mathrm{H}_{2} \mathrm{O}, 0.5 \mathrm{~g}$; asparagine (recrystallized from ethanol), $1.0 \mathrm{~g}$.; inositol, $40.0 \mathrm{mg}$.; thiamine, $400.0 \mu \mathrm{g}$.; biotin, $2.5 \mu \mathrm{g}$.; water to $1000 \mathrm{ml}$. When experiments were made with ${ }^{35} \mathrm{SO}_{4}, \mathrm{MgCl}_{2}$ (0.31 g.) was substituted for $\mathrm{MgSO}_{4} \cdot 7 \mathrm{H}_{2} \mathrm{O}$ (Robson, 1958). The media in experiments with ${ }^{35} \mathrm{SO}_{4}$ and in experiments for measuring the - $\mathrm{SH}$ content of the organism contained $\mathrm{SO}_{4}$ as the only added source of sulphur. The medium was adjusted to $\mathrm{pH} 6 \cdot 4,40 \mathrm{ml}$. of culture fluid were dispensed into $250 \mathrm{ml}$. sonical flasks and sterilized by autoclaving at $121^{\circ}$ for $20 \mathrm{~min}$.

Preparation of the inoculum. A suspension of conidia or yeast cells was prepared by washing an agar slope with sterile water and shaking the decanted suspension vigorously. A loopful of this suspension was used to inoculate the medium. The inoculum of Eremothecium ashbyii was prepared by cutting pieces of mycelium from an agar slope. The nutrient ag.ur had the same formula as the culture fluid and contained $1.5 \%(\mathrm{w} / \mathrm{v})$ agar; the inc culum was between 10 days and 3 weeks old.

Temperature of incubation. Cultures were incubated at $30^{\circ}$ or $22^{\circ}$ in the dark.

Determination of ${ }^{35} \mathrm{~S}$ in the fungus. Estimations of the amount of ${ }^{35} \mathrm{~S} / \mathrm{mg}$. dry weight were made for three or four replicate cultures as described by Robson (1958). Individual measurements of the specific activity of the fungus were plotted against the age of the fungus.

\section{Estimation of sulphydryl compounds}

In the culture fluid. Culture flid from three or four replicate cultures was separated from the mycelium, pooled and evaporated to a small volume in the frozen state on a vacuum line. The volume of medium was adjusted to about $10 \mathrm{ml}$. and $0 \cdot 1 \mathrm{ml}$. of a solution of phenyl ricercuric chloride $\left({ }^{203} \mathrm{Hg}\right)$ in dioxan $\left(7 \cdot 4 \times 10^{-3} \mathrm{M}\right)$ was added to it. The solutions were agitated and allowed to stand for $15 \mathrm{~min}$. The solids in the medium were precipitated with $80(\mathrm{v} / \mathrm{v})$ ethanol in water, and further material allowed to crystallize out overnight at $0^{\circ}$. The precipitated solids were washed three times with dioxan to remove excess phenyl mercuric chloride. The amounts of ${ }^{203} \mathrm{H} g$ in solids were det $ə$ rmined by counting the emitted $\gamma$-radiation in a well-type scintillation counter.

In the fungus. Measurements were nade of the $-\mathrm{SH}$ content $/ \mathrm{mg}$. tissue individually for three or four replicates. First, the fungus was washed twice with distilled water and the washings centrifuged off from the mycelium. The mycelium was suspended 
in about $2 \mathrm{ml}$. of water and $0 \cdot 1 \mathrm{ml}$. of a $7 \cdot 4 \times 10^{-3} \mathrm{M}$-dioxan solution of $\mathrm{C}_{6} \mathrm{H}_{5}{ }^{203} \mathrm{HgCl}$ added. Fifteen minutes were allowed for the reagent to penetrate the tissues. Excess reagent was removed three times with dioxan and the amount of ${ }^{203} \mathrm{Hg}$ combined in the fungus was measured on the $\gamma$-scintillation counter. The dry weight of the fungus was determined by drying the fungus at $60^{\circ}$ on weighed aluminium planchets.

\section{Localization of $-\mathrm{SH}$ in cells}

The organisms at various stages of development were freeze-dried, embedded in paraffin wax and sectioned at $2 \mu$ (Robson, 1960). The de-waxed sections were treated with a dioxan solution of tritiated phenyl mercuric chloride $\left(5 \cdot 4 \times 10^{4} \mathrm{M}\right)$ for $15 \mathrm{~min}$. Excess reagent was removed by placing the slides in three changes of dioxan for $5 \mathrm{~min}$. each and in two changes of acetone $(15 \mathrm{~min}$.). The specimens were coated by immersing them in a $1 \%(\mathrm{v} / \mathrm{v})$ solution of Zapon (I.C.I.). The coating was necessary because freeze-dried yeast cells will reduce a photographic emulsion. Autoradiographs were prepared as previously described (Robson, 1960). Specimens were exposed to film for about 1 month before development.

\section{Preparation of radioactive reagents}

$\mathrm{C}_{6} \mathrm{H}_{5}{ }^{203} \mathrm{HgCl}$. One g. $\mathrm{HgO}$ was irradiated for 3 weeks at a flux of $3 \cdot 3 \times 10^{12}$ neutrons $/ \mathrm{cm}^{2} . / \mathrm{sec}$. The irradiation produced two radioactive isotopes of $\mathrm{Hg},{ }^{197} \mathrm{Hg}$ and ${ }^{203} \mathrm{Hg}$, which gave a total of about $4 \mathrm{c}$. of radioactivity in the sample. The irradiated material was kept for 1 week before processing to allow some of the shortlived ${ }^{197} \mathrm{Hg}\left(t_{\frac{1}{2}}=65 \mathrm{hr}\right.$.) to decay. $\mathrm{HgO}$ was dissolved in an equivalent amount of $\mathrm{HCl}$ and the solution allowed to evaporate to dryness. The $\mathrm{HgCl}_{2}$ formed was dissolved in $9 \mathrm{ml}$. acetone and added to a $\left(\mathrm{C}_{6} \mathrm{H}_{5}\right)_{2} \mathrm{Hg}$ solution containing $\mathbf{1} \cdot 61 \mathrm{~g}$. in $9 \mathrm{ml}$. acetone. A white crystalline precipitate of $\mathrm{C}_{6} \mathrm{H}_{5} \mathrm{HgCl}$ formed immediately. The supernatant acetone was centrifuged off and the $\mathrm{C}_{6} \mathrm{H}_{5} \mathrm{HgCl}$ dissolved in hot xylene. The xylene solution was filtered hot and crystalline $\mathrm{C}_{6} \mathrm{H}_{5} \mathrm{HgCl}$ recovered on cooling. The material was recrystallized again from xylene. The yield was about $0.6 \mathrm{~g}$. and the specific activity $\left({ }^{203} \mathrm{Hg}\right.$ only) after 1 month was about $14 \mathrm{mc} . / \mathrm{g}$. For use as a reagent this material was dissolved in $250 \mathrm{ml}$. dioxan. The radiochemical purity was checked on a $\gamma$-spectrometer; no $\gamma$-emitting isotopes other than ${ }^{208} \mathrm{Hg}$ were detected.

Tritiated $\mathrm{C}_{6} \mathrm{H}_{5} \mathrm{HgCl}$. Twenty-five $\mathrm{mg}$. (10 mc.) of aniline (tritiated generally) were dissolved in $1.0 \mathrm{ml}$. of a solution containing $0.27 \mathrm{~g}$. $\mathrm{HCl}$ and $0.67 \mathrm{~g}$. $\mathrm{HgCl}$. The mixture was cooled to $2^{\circ}$, and $1 \mathrm{ml}$. $\mathrm{NaNO}_{2}(0 \cdot 17 \mathrm{~g}$. $)$ solution added. The white complex formed was decomposed by adding $2 \mathrm{ml}$. of a suspension of cuprous chloride in $80 \%(\mathrm{w} / \mathrm{v})$ ethanol in water $\left(2 \mathrm{ml}\right.$. solution containing $\left.50 \mathrm{mg} . \mathrm{Cu}_{2} \mathrm{Cl}_{2}\right)$. The $\mathrm{C}_{6} \mathrm{H}_{5} \mathrm{HgCl}$ was extracted from the reaction mixture with xylene and recrystallized. The yield was about $60 \mathrm{mg}$. with specific activity about $120 \mathrm{mc} . / \mathrm{mg}$. The $\mathrm{C}_{6} \mathrm{H}_{5} \mathrm{HgCl}$ was dissolved in dioxan and the solution used to treat sections was approximately $5 \cdot 4 \times 10^{-4} \mathrm{M}$.

\section{RESULTS}

Aspergillus niger

Each graph in Figs. 1 and 2 represents three experiments carried out at different times. Figures $1 a$ and $1 b$ illustrate the changes in ${ }^{35} \mathrm{~S}$ concentration and $-\mathrm{SH}$ concentration (measured with ${ }^{203} \mathrm{Hg}, \mathrm{C}_{6} \mathrm{H}_{5} \mathrm{HgCl}$ ) in relation to dry weight as the 
fungus grew at $22^{\circ}$. This temperalure was below the optimum for the growth of this organism. During the first 24 or. the conidia germinated and the fungus grew steadily for $168 \mathrm{hr}$. in the medium (Fig. $1 b$ ) but ceased to grow regulitrly after $72 \mathrm{hr}$. when the medium contained a small amount of ${ }^{35} \mathrm{SO}_{4}$. Germination was accompanied by a decrease in the ${ }^{-\mathrm{SH}}$ content of the fungus. The conidia contained no ${ }^{35} \mathrm{~S}$ before they were placed in the medium, but during the first 24 lır. they took up ${ }^{35} \mathrm{~S}$ from their surroundings. During the following $24 \mathrm{hr}$. both the ${ }^{35} \mathrm{~S}$ content/mg. dry weight and the SH content mg. dry weight of the fungus increas 2 d. After $48 \mathrm{hr}$. both ${ }^{35} \mathrm{~S}$ and $-\mathrm{SH}$ concentrations
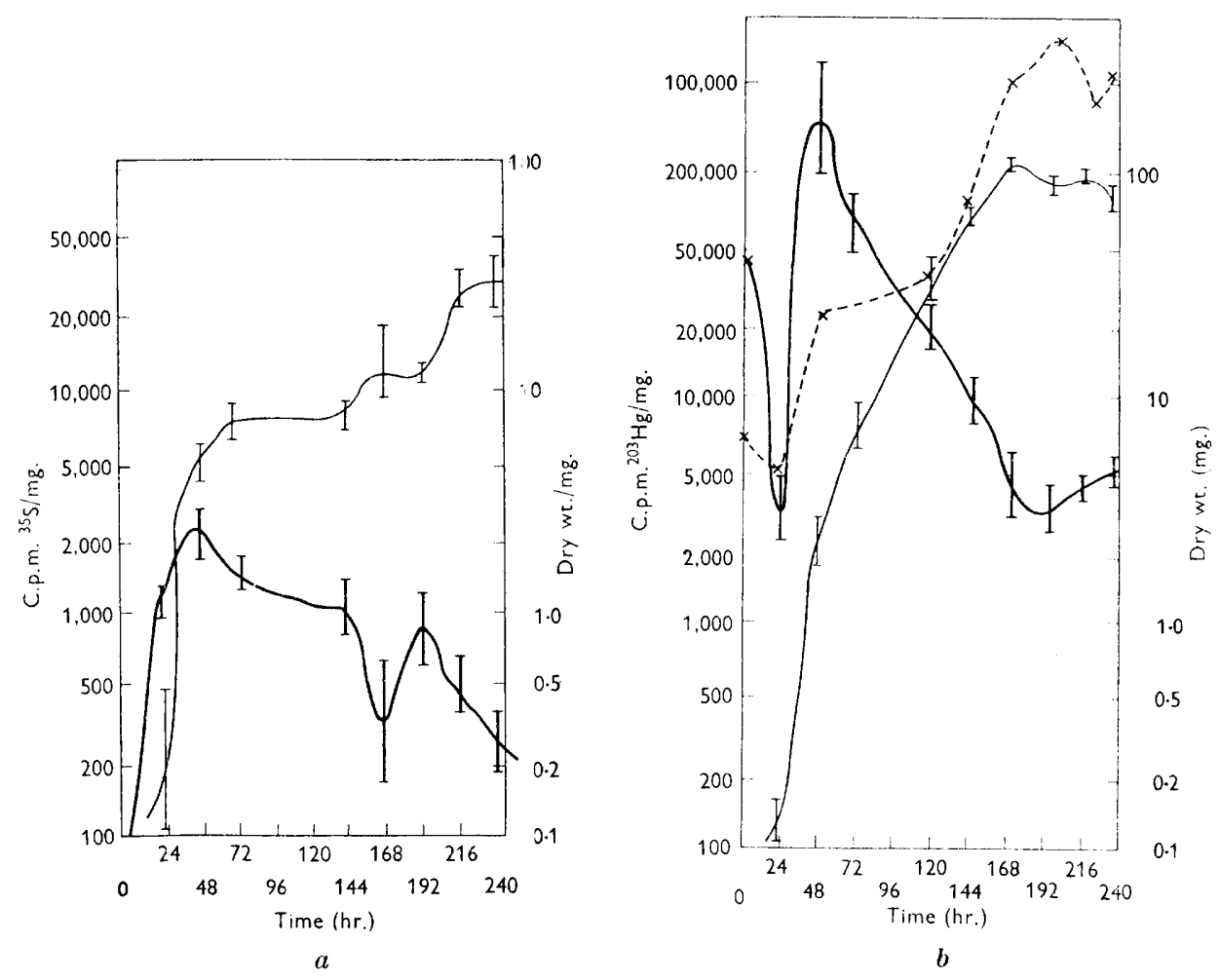

Fig. 1a. Aspergillus niger grown at $22^{\circ}$. Changes in the ${ }^{35} \mathrm{~S}$ content of the mycelium during growth. --, Dry wt.; $-{ }^{35} \mathrm{~S}$ ir the fungus.

Fig. 1 b. Aspergillus niger grown at $\leq 2^{\circ}$. Changes in the $-\mathrm{SH}$ content of the mycelium and culture fluid during growth. —, sH/mg. dry wt.; - - , SH in medium; - , dry wt.

reached a maximum. Further development of the fungus was accompanied by a decline in both ${ }^{35} \mathrm{~S} / \mathrm{mg}$. dry weight and $-\mathrm{SH} / \mathrm{mg}$. dry weight. Between 168 and $192 \mathrm{hr}$. the ${ }^{35} \mathrm{~S}$ content of the mycelium increased somewhat then declined until the experiment finished. The -SH content of the fungus stopped declining after $168 \mathrm{hr}$. and increased slightly until $240 \mathrm{hr}$. The changes in -SH content during the period $168-240 \mathrm{hr}$. did not reflect the changes in ${ }^{35} \mathrm{~S}$ content but appeared to be inversely proportional to them. Some -SH-containing compounds may have been combined with $\mathrm{S}$ compounds absorbed from the medium during the period 168$192 \mathrm{hr}$. 
The -SH content of the medium increased almost continually throughout the experiment. Some $-\mathrm{SH}$ compounds may be excreted after about $48 \mathrm{hr}$. The mycelial ${ }^{35} \mathrm{~S}$ and $-\mathrm{SH}$ decreased at that time and the $-\mathrm{SH}$ content of the medium increased.

At $30^{\circ}$, which is almost the optimum temperature for the growth of Aspergillus niger, growth finished after $96 \mathrm{hr}$. in the full $-\mathrm{SO}_{4}$ medium and after $48 \mathrm{hr}$. in the ${ }^{35} \mathrm{SO}_{4}$ medium (Fig. 2). At this temperature the $-\mathrm{SH}$ content of the fungus also decreased when the conidia germinated. The maximum -SH concentration was reached after $48 \mathrm{hr}$. during the growth phase $\left(24-96 \mathrm{hr}\right.$.). The ${ }^{35} \mathrm{~S}$ concentration reached a maximum within $24 \mathrm{hr}$. and a high concentration was maintained until $60 \mathrm{hr}$. 'The ${ }^{35} \mathrm{~S}$ content fell steadily from 60 to $98 \mathrm{hr}$. (growth finished after $48 \mathrm{hr}$.) but increased from 96 to $144 \mathrm{hr}$. then decreased steadily to the end of the experiment. No decrease in - SH sulphur occurred, which corresponded to the decrease in ${ }^{35} \mathrm{~S}$ content that followed cessation of growth. However, $-\mathrm{SH}$ content increased then decreased during the period in which no growth occurred (96-240 hr.) in a similar way to the change in ${ }^{35} \mathrm{~S}$ content which took place between 96 and $240 \mathrm{hr}$.
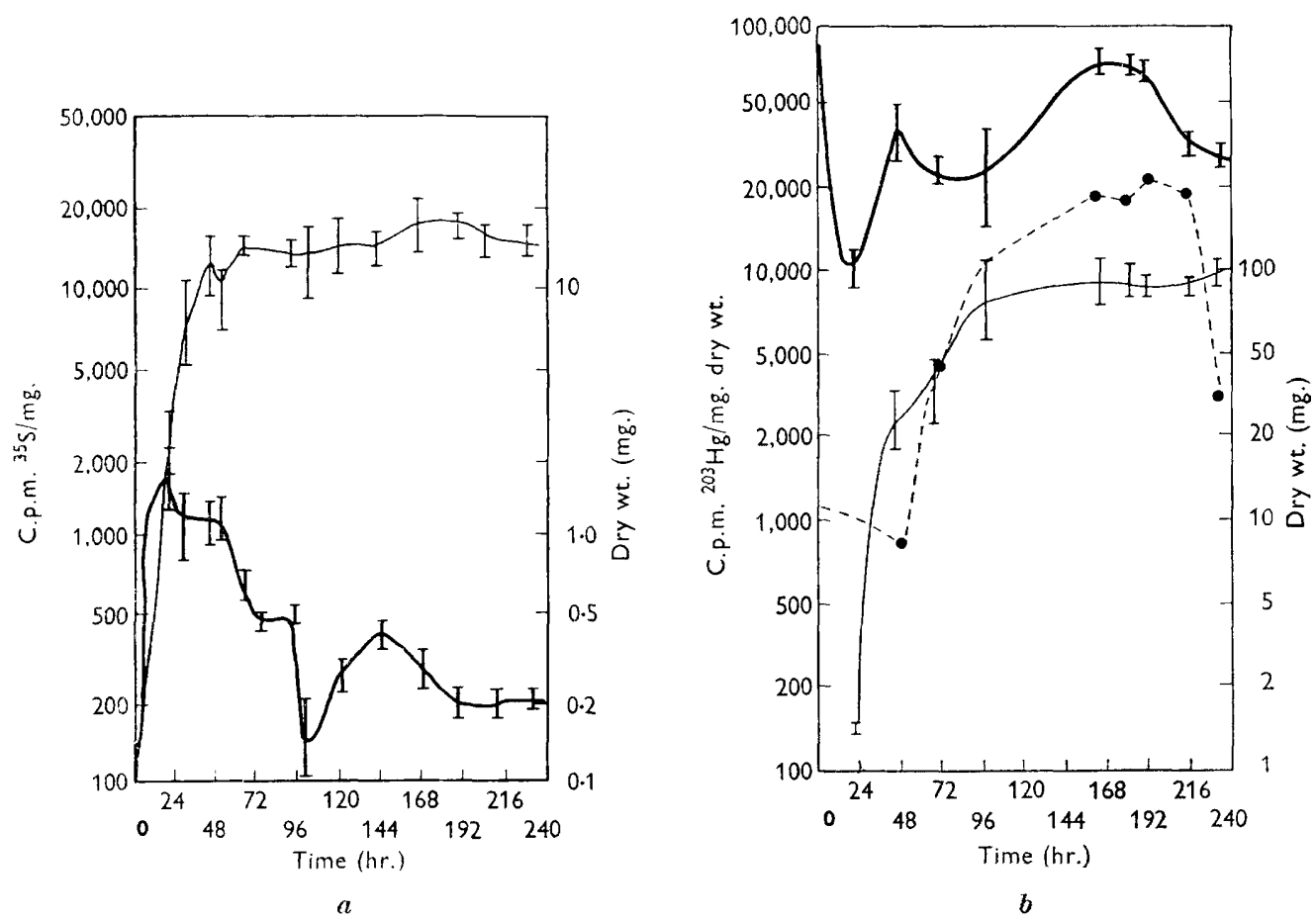

Fig. 2a. Aspergillus niger grown at $30^{\circ}$. Changes in the ${ }^{35} \mathrm{~S}$ content of the mycelium during growth. -, ${ }^{35}$ S c.p.m./mg. dry wt.; - , dry wt. (mg.).

Fig. 2b. Aspergillus niger grown at $30^{\circ}$. Changes in the $-\mathrm{SH}$ content of the mycelium and culture fluid during growth. - , SH/mg. dry wt.; - - , SH present in the medium; -, dry wt.

The -SH content of the medium increased from 48 to $144 \mathrm{hr}$., remained steady for $72 \mathrm{hr}$., then fell sharply. The -SH compounds in the medium did not increase as a result of the loss of $-\mathrm{SH}$ compounds from the fungus. However, the ${ }^{35} \mathrm{~S}$ content 
of the fungus fell when growth finished; possibly S-containing substances were converted into others in the medium that contained -SH.

Growth of the fungus at a higher temperature considerably altered its -SH content.

Cytological studies. Both ${ }^{35} \mathrm{~S}$ and -SH were present in the cell-wall region in the young hyphae $\left(48 \mathrm{hr}\right.$.). As the fungus aged, both ${ }^{35} \mathrm{~S}$ compounds and $-\mathrm{SH}$ were distinct in the cytoplasm but not obvious in the cell wall. In older hyphae ( 8 days) there was a strong association of $-\mathbf{S H}$ with the nucleus but not obviously with the cytoplasm behind the hyphal tip (Pl. 1, figs. 1, 2). Some hyphae were twice as wide as others at this stage and the wide hyphae had a stronger $-\mathrm{SH}$ reaction than the thin ones.

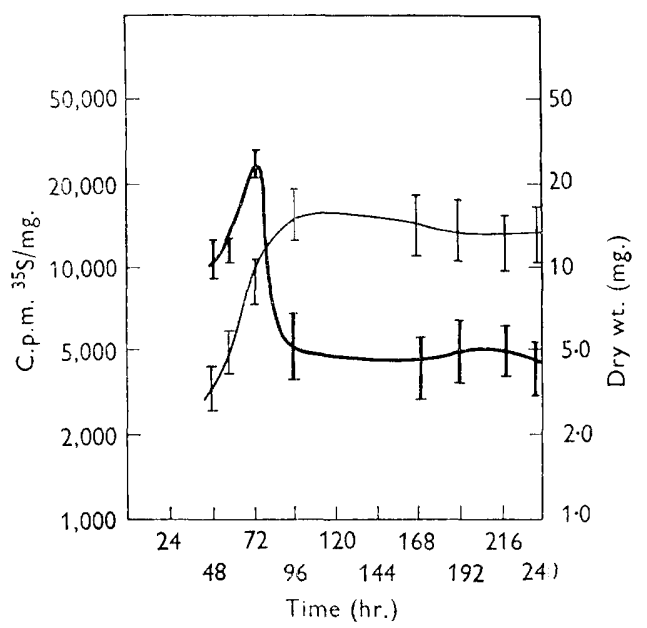

$a$

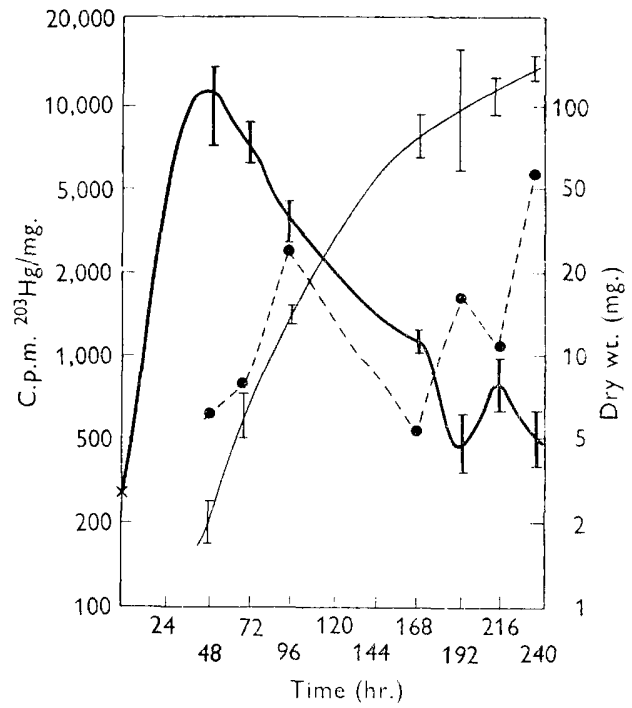

$b$

Fig. 3a. Penicillium chrysogenum 49 .133. Grown at $22^{\circ}$. Changes in the ${ }^{35} \mathrm{~S}$ content of the mycelium during growth. - , ${ }^{3} \mathrm{~S} / \mathrm{mg}$. dry wt.; -, mg. dry wt.

Fig. 3b. Penicillium chrysogenum 9.133. Grown at $22^{\circ}$. Changes in the $-\mathrm{SH}$ content of the mycelium and culture medit m during growth. - , Dry wt.; - - , SH present in the medium; -, SH/mg. dry wt.

\section{Penicilli «m chrysogenum 49.133}

Figure $3 a$ represents the results of three separate experiments and shows the changes in ${ }^{35} \mathrm{~S}$ concentration during; the growth of $P$. chrysogenum 49.133 . Figure $3 b$ represents two experiments in wl ich the conidia had a low $-\mathrm{SH}$ content. In the third experiment the conidia had a $-\mathrm{SH}$ content six times as high as the highest mycelial concentration. The reascn for the high $-\mathrm{SH}$ content of the conidia is not known, but the viability of the conidia was not affected by the amount of -SH compounds they contained. When the conidia had a high -SH content, the - $\mathrm{SH}$ content of the fungus decreased with germination. When the conidia contained small amounts of -SH compouncs, the - SH content of the fungus increased on germination. The sulphydryl growth pattern appeared to be unaltered by the -SH 
content of the conidia. The fungus grew from 48 to $240 \mathrm{hr}$. in the medium which contained the full amount of sulphate and grew from 48 to $96 \mathrm{hr}$. in the medium containing ${ }^{35} \mathrm{SO}_{4}$. The $-\mathrm{SH}$ content of the fungus reached a maximum $24 \mathrm{hr}$. before the ${ }^{35} \mathrm{~S}$ content reached a maximum but did not drop so sharply as the ${ }^{35} \mathrm{~S}$ content of the fungus after the peak concentration. A slight fluctuation in the - SH content of the fungus occurred between 192 and $240 \mathrm{hr}$. and this was not reflected in the ${ }^{35} \mathrm{~S}$ content of the fungus. The optimum temperature for the growth of $\boldsymbol{P}$. chrysogenum 49.133 is almost $22^{\circ}$, but the $-\mathrm{SH}$ metabolism was very different in the later period from the metabolism of Aspergillus niger grown at the optimum temperature. The changes in ${ }^{35} \mathrm{~S}$ content were not caused solely by the changes in $-\mathrm{SH}$ content in either of these fungi.

Between 72 and $96 \mathrm{hr}$. a rapid drop in the ${ }^{35} \mathrm{~S}$ content of the mycelium occurred; during this period the -SH content of the fungus also declined. The drop in - SH content and ${ }^{35} \mathrm{~S}$ content of the fungus occurred at the same time as the $-\mathrm{SH}$ content of the medium increased. Compounds were probably excreted at this phase. From 96 to $168 \mathrm{hr}$. the $-\mathrm{SH}$ content of the medium decreased sharply; during this period the sulphur may have been oxidized extracellularly. After $168 \mathrm{hr}$. the changes which occurred in the $-\mathrm{SH}$ content of the medium and the fungus were inversely related to one another. Possibly an exchange of metabolites occurred.

Cytological studies. ${ }^{35} \mathrm{~S}$ was present in abundance in the cytoplasm of the hypha but not obviously in the cell wall. Similarly, $-\mathrm{SH}$ was present in the cytoplasm but not in the cell wall at all stages. However, it is not always easy to distinguish wall -SH when the autoradiograph above the cytoplasm is quite dense.

\section{Eremothecium ashbyii}

This fungus differed from the other three organisms because the hyphal inoculum did not begin to grow in the medium until some time had elapsed. Figure $4 a$ shows the changes in ${ }^{35} \mathrm{~S}$ concentration in $E$. ashbyii, which began to grow in the medium after 3 days at $30^{\circ}$. It represents three experiments. Figures $4 b$ and $4 c$ show changes in $-\mathrm{SH}$ content of this fungus; Fig. $4 b$ represents three experiments with a strain that grew after a lag period of $90 \mathrm{hr}$., and Fig. $4 c$ the results of three experiments when the fungus grew after $48 \mathrm{hr}$. at $30^{\circ}$.

The final dry weight of the fungus was smaller when the medium contained ${ }^{35} \mathrm{SO}_{4}$ only, than when the full amount of $-\mathrm{SO}_{4}$ was used. This response was the same as that of Aspergillus niger and Penicillium chrysogenum to small amounts of $-\mathrm{SO}_{4}$ in the medium. Figure $4 a$ shows that the ${ }^{35} \mathrm{~S}$ content of the mycelium reached a maximum during a period when no growth occurred (in the first $72 \mathrm{hr}$.). When growth began $\left(72 \mathrm{hr}\right.$. onwards), the ${ }^{35} \mathrm{~S}$ content fell sharply at first. Figure $4 b$ shows that the -SH content of the fungus rose, fell and rose again before growth began. The early growth phase was accompanied by a drop in - $\mathrm{SH}$ content of the fungus which paralleled the drop in ${ }^{35} \mathrm{~S}$ content. The ${ }^{35} \mathrm{~S}$ content increased sharply as the growth rate dropped but no comparable increase occurred in - $\mathrm{SH}$ content during a similar period. Figure $4 c$ shows that fluctuations in $-\mathrm{SH}$ content did not occur initially when the lag period lasted for about $48 \mathrm{hr}$. (compared with Fig. $4 b$ ). The - $\mathrm{SH}$ content of the mycelium decreased without fluctuation during the later growth phase, but otherwise the relative decreases in $-\mathrm{SH}$ after $96 \mathrm{hr}$. in Fig. $4 b$ and Fig. $4 c$ were similar. 
The changes in the $-\mathrm{SH}$ con ent of the fungus and the $-\mathrm{SH}$ content of the medium were inversely related to one another for $216 \mathrm{hr}$. During the lag period the changes in - $\mathrm{SH}$ content of the myceli $\mathrm{im}$ and medium suggest that $-\mathrm{SH}$ compounds were metabolized extracellularly and then taken up by the fungus. During the later growth phase the ${ }^{35} \mathrm{~S}$ content of the mycelium changes little, although the -SH content of the fungus declined and that of the medium increased. Possibly SH compounds were excreted int, the medium during this phase and were replaced by sulphur in the oxidized state in the fungus.

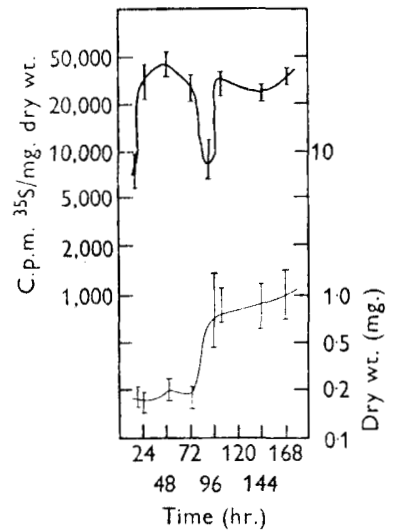

$a$

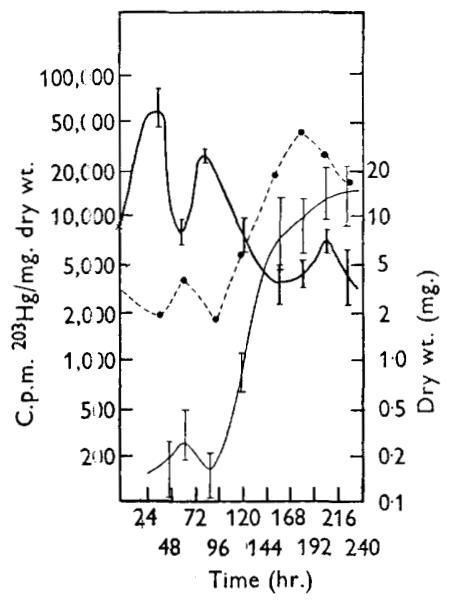

$b$

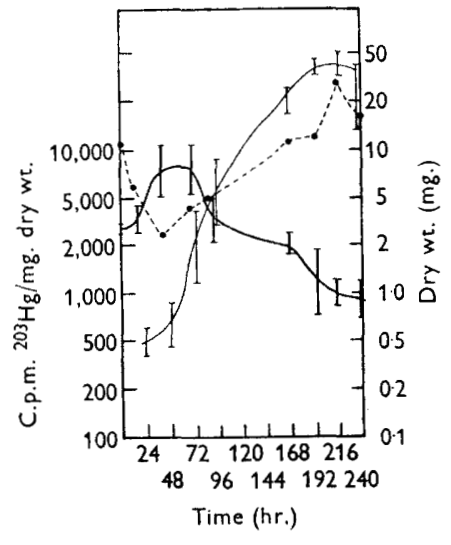

$c$

Fig. 4a. Eremothecium ashbyii. Lag period of $72 \mathrm{hr}$, grown at $30^{\circ}$. Changes in ${ }^{35} \mathrm{~S}$ content during growth. - ${ }^{35} \mathrm{~S} n$ the fungus; - , dry wt.

Fig. 4b. Eremothecium ashbyii. Lag period of $90 \mathrm{hr}$, grown at $30^{\circ}$. Changes in -SH content of the mycelium and culture fluid during growth. - $\mathrm{SH}$ in fungus; - - $\mathrm{SH}$ in medium; - - dry wt.

Fig. 4c. Eremothecium ashbyii. Short lag period, grown at $30^{\circ}$. Changes in the $-\mathrm{SH}$ content of the mycelium and culture fluid during growth. - , SH in fungus; - --, SH in the medium; - dry wt.

Cytological studies. Most of $t e^{35} \mathrm{~S}$ and $-\mathrm{SH}$ compounds were present in the cell wall (Pl. 1, figs. 3, 4) and some ${ }^{35 ;}$; and-SH compounds were present in the cytoplasm in the later growth phase. $\mathbf{H}_{\gamma}$ phae were differentiated when growth was well established into wide mature types and young growing forms. The mature hyphae had a very strong - SH reaction in the cell wall, the fine hyphae had a weak reaction (Pl. 1, fig. 5). In the fine hyphae ${ }^{35} \mathrm{~S}$ and $-\mathrm{SH}$ compounds appeared to be less concentrated and more - $\mathrm{SH}$ and ${ }^{35} \mathrm{~S}$ compounds were present in the cytoplasm than in the cell wall. Hyphal tips had no obvious -SH in the cytoplasm and little present in the cell wall (see Pl. 2, figs. 12-15). A very strong -SH reaction occurred in the walls of a wide hypha when a bud developed (Pl. 1, figs. 6, 7). 'This strong reaction remained at the base $\mathrm{o}$ : a bud after it had elongated ( $\mathrm{Pl}$. 2, figs. 8, 9).

\section{Candida albicans}

The yeast in the medium contiining the full amount of $-\mathrm{SO}_{4}$ grew for $168 \mathrm{hr}$. and reached a higher total dry wei; 
growth during the first $24 \mathrm{hr}$. was faster in the $-\mathrm{SO}_{4}$ medium and the growth curves from the two experiments are not very similar although both were made at $30^{\circ}$. However, during the first $48 \mathrm{hr}$. both ${ }^{35} \mathrm{~S}$ and $-\mathrm{SH}$ contents of the yeast reached a maximum (Figs. $5 a$ and $5 b$ ).

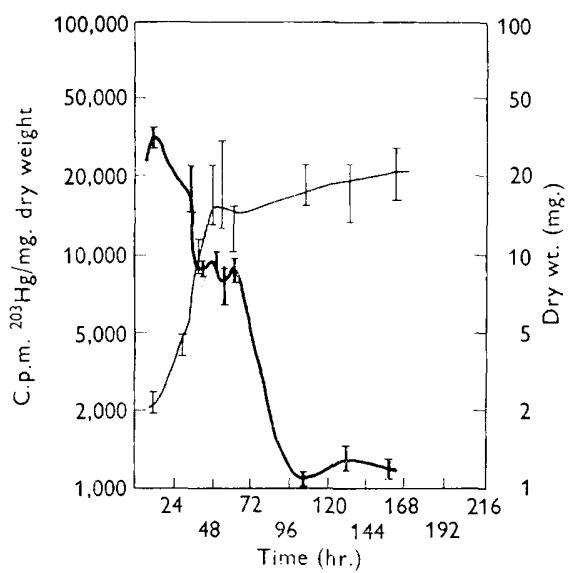

$a$

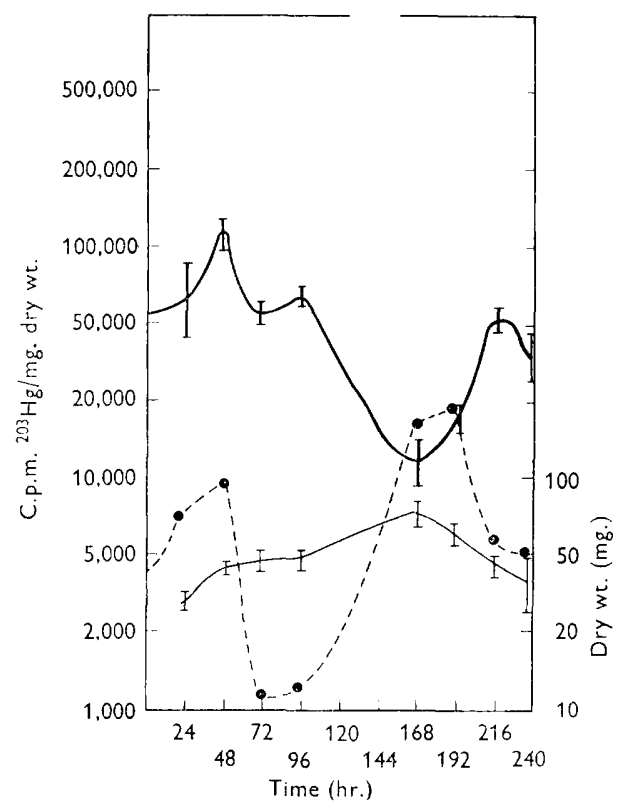

b

Fig. 5a. Candida albicans. Changes in the ${ }^{35} \mathrm{~S}$ content of the yeast during growth. ,$-{ }^{35} \mathrm{~S}$ in yeast; - - dry wt.

Fig. $5 b$. Candida albicans. Changes in the $-\mathrm{SH}$ content of the cells and culture fluid during growth. - $\mathrm{SH}$ in yeast; - - , SH in medium; - dry wt.

The maxima were followed by a decrease in both ${ }^{35} \mathrm{~S}$ and $-\mathrm{SH}$ concentrations The yeast in the ${ }^{35} \mathrm{SO}_{4}$ did not autolyse, but autolysis in the full $-\mathrm{SO}_{4}$ medium was accompanied by an increase in the - $\mathrm{SH}$ concentration in the cell.

The ${ }^{35} \mathrm{~S}$ of the yeast fell rapidly in the later stages of growth but only during a certain phase (96-168 hr.) did - $\mathrm{SH}$ sulphur in the medium increase as a result. During this phase the - $\mathrm{SH}$ content of the yeast also decreased. In the early stages - SH compounds formed in the medium did not appear to pass into the cell nor did -SH compounds formed in the cell pass into the medium. During the period of autolysis the -SH content of the medium declined sharply. This may have occurred as a result of reactions in the medium between the autolysis products and the - SH compounds already present. Alternatively, the presence of the products of autolysis may have induced the living yeast cells to absorb -SH products from the medium.

Cytological studies. The strain of yeast used in these experiments grew almost exclusively by budding. After about 10 days small filaments appeared but the mycelial phase was not strongly represented. Autoradiographs showed -SH in the cell walls of yeasts aged $24 \mathrm{hr} .-6$ days (Pl. 2, figs. 10, 11). Autoradiographs of the yeast which had been grown on potato agar showed -SH in round cells but not in the filaments. These autoradiographs were obtained after six weeks exposure. 


\section{DISCUSSION}

Changes in the concentratio 1 of both ${ }^{35} \mathrm{~S}$ and $-\mathrm{SH}$ compounds that occurred during the development of the fungus cell were probably influenced by the extracellular metabolism of sulphur while other changes resulted in the excretion of S-containing substances into the medium. Sulphur compounds play an important role in metabolic changes which take place in both cell wall and cytoplasm of the fungus. The accumulation of ${ }^{35} \mathrm{~S}$ compounds in the fungi could not be wholly related to the accumulation of - $\mathrm{SH}$ compounds in all the experiments. When Aspergillus niger was grown at $22^{\circ}$ the cone ntrations of ${ }^{35} \mathrm{~S}$ compounds could be correlated with the accumulation of -SH compo ands. A similar relationship occurred in experiments with Eremothecium ashbyii and Candida albicans in the early growth phase. During the later stages of development changes in the ${ }^{35} \mathrm{~S}$ content of the fungus did not always cause similar changes in $-\mathrm{SH}$ content $\left(A\right.$. niger at $30^{\circ}$ and $E$. ashbyii). However, in all the experimer.ts, $-\mathrm{SH}$ compounds were concentrated in the cell during the early growth period whether the cell had a high total $S$ content simultaneously or not. In this respest the young hypha is chemically similar to the meristematic cell of higher plants. Gola (1903) was the first to detect high concentration of SH compounds in plant meris tems by using the nitroprusside test. Gola's observations were confirmed by Ham nett \& Chapman (1938), who analysed the various regions of the root of Phaseous vulgaris, and also by Pilet (1957) who analysed the root of Lens. Hammett \& Chapman correlated a high cellular -SH content with mitosis and a low one with cell elongation. The young hypha grows mainly by cell elongation, but the similarity hetween the high -SH content of the young growing fungus cell and the meristematic cell suggests that common reactions are occurring.

The formation of extracellular compounds by fungi is not a new phenomenon. Morton \& Broadbent (1955) described the formation of extracellular nitrogencontaining compounds by Aspergillus niger and Penicillium chrysogenum. These studies show that extracellular -SH containing compounds are also produced by these fungi and by Eremothecium a:hbyii and Candida albicans. The formation of these -SH compounds usually deper ded upon changes in the - $\mathrm{SH}$ content of the fungus. The only evidence for the fornation of extracellular compounds which were later absorbed by the fungus came $\mathrm{f}$ rom experiments with $E$. ashbyii and $P$. chrysogenum 49.133. Occasionally $\mathrm{S}$ could be lost from the fungus without affecting its $-\mathrm{SH}$ content and yet increase the $-\mathrm{S} \mathrm{iH}$ content of the medium $\left(A\right.$. niger at $30^{\circ}, C$. albicans 48-72 hr.). This phenomenon could be explained if one assumed that the $\mathrm{S}$ excreted was reduced to $-\mathrm{SH}$ in the medium. Previous reactions in the medium in which a fungus was growing were described by Tardrew \& Johnson (1959) who analysed the medium from a penicillin fermentation.

Cytological studies on the clistribution of ${ }^{35} \mathrm{~S}$ and $-\mathrm{SH}$ compounds indicated the sites at which active metabol sm of these substances occurred. The concentrations of $-\mathrm{SH}$ compounds in the cel wall and cytoplasm were not the same for all the organisms studied. They can be divided into two groups on the basis of the -SH reaction of the cell wall. Can lida albicans and Eremothecium ashbyii have a strong wall sulphydryl reaction, whereas Aspergillus niger and Penicillium chrysogenum 49.133 have a weak reaction. These groups reflect the taxomonic groupings of these organisms, for $C$. albicans anc $E$. ashbyii belong to the Saccharomycetales, $A$. niger 
and $\boldsymbol{P}$. chrysogenum to the Aspergillaceae. However, the fundamental reason for the difference in -SH wall reaction may be connected with the two distinct ways of branch formation found in the two groups of organisms. E. ashbyii and C. albicans form buds on mature cell walls, whereas bifurcations of the hypha occur at the hyphal tip in $A$. niger and $P$. chrysogenum. Nickerson \& Falcone (1958) showed that $-\mathrm{SH}$ bonds are formed in the wall at the region of bud formation in $C$, albicans. The formation of -SH bonds in the protein of the cell wall allow re-orientation of the wall fibrils. The cell wall is plastic where re-arrangement has occurred and can extend in a new dimension. Thus the higher wall -SH is associated with bud formation on a mature cell wall. Further support for this theory can be deduced from a study of the sulphydryl reaction at the hyphal tips of these organisms. No strong sulphydryl reaction was noticed in the hyphal tips of the three fungi studied. In E. ashbyii there was a marked difference in $-\mathrm{SH}$ reaction at the tip ( $\mathrm{Pl}$. 2, figs. 5-8) and the very strong reaction at the site of hyphal budding (Pl. 1, fig. 6). Middlebrook \& Preston (1952) studied the hyphal tip of Phycomyces and discovered that fibrils at the tip were transversely orientated and that the cell wall in this region was very fine. Fibrils 1-2 mm. from the hyphal tip were arranged both axially and transversely and the wall was thickened by apposition of materials. Since the fibrils at the tip are few and oriented mainly in one direction, it is probable that bifurcation can occur without fibril re-arrangement. Therefore sulphydryl compounds are not concentrated in this area. Differences in the intensity of the -SH wall reaction could also occur as the result of different cell wall composition in these organisms. The walls of the four species have not been completely analysed, but Nickerson found glucan, mannan and S-containing protein in the wall of C. albicans, and Frey (1952) found chitin in the walls of Aspergilli and Penicillia but not in the wall of $\boldsymbol{E}$. ashybii; Rzucidko, Stachow, Nowankowska \& Kubica (1950) found $7 \cdot 3 \%(\mathrm{w} / \mathrm{v})$ protein in the wall of Penicillium notatum. The carbohydrate constituents of the cell wall vary, but protein has been described in two species and may occur in all. Zalokar (1959) noted that the nucleoli of Neurospora crassa gave a positive -SH reaction when treated with Barnett and Seligman's reagents. In these studies with a radioactive cytological reagent, a relation was noted between the autoradiograph and nuclear areas in $A$. niger.

Nickerson \& Falcone's (1958) expectation that -SH compounds in the region of bud formation could be demonstrated with a suitable cytological reagent has been realized in these experiments. The results with Eremothecium ashbyii were satisfactory but sufficient material of the yeast was not studied. Radioactive cytological reagents can be extremely valuable since their detection in the cell is not dependent on colour groupings in the molecule.

The authors thank Dr G. B. Cook for helpful discussions during this work and Mr J. Eveleigh of this laboratory for the preparation of tritiated phenyl mercuric chloride.

\section{REFERENCES}

Frex, R. (1952). Chitin and cellulose in fungal cell walls. Ber. schweiz. bot. Ges. 60, 199. GolA, G. (1903). Lo zolfi e suoi compositi nell' economia delle piante. Malpighia, 16, 368. Hammetr, F. S. \& Chapman, S. S. (1938). A correlation between sulphydryl, mitosis and cell growth in length in Phaseolus vulgaris. Growth, 2, 297. 
Hellerman, L., Perkins, M. E. \& Clark, M. (1933). Urease activity as influenced by oxidation and reduction. Proc. net. Acad. Sci., Wash. 19, 855.

Hughes, W. L. (1950). Protein mercaptides. Cold Spr. Harb. Symp. Quant. Biol. 14, 79.

Janke, A., Beran, R. \& SchmidT, G. (1953). Über die Einwirkung von Schwermetallsalzen auf Brandpilze. PflSchBer. 10, 65.

Middlebrook, M. J. \& Preston, F. D. (1952). Spiral growth and spiral structure. III. Wall structure in the growth zont: of Phycomyces. Biochim. biophys. Acta, 9, 32.

Monton, A. G. \& Broadbent, D. 1955). 'The formation of extracellular nitrogen compounds by fungi. J. gen. Microbi,l. 12, 248.

Nickerson, W. J. \& Falcone, G (1958). Function of protein disulfide reductase in cellular division of yeasts. Sulphur in Proteins, Proc. Symp. Falmouth, Mass., p. 424. Ed. R. Benesch. New York: Academic Press.

Olcott, H. S. \& Fraenkel-Conr it, H. (1947). Specific group reagents for proteins. Chem. Rev. 41, 151.

PILET, P. E. (1957). Distribution les groups sulphydryles (-SH), activités des auxinesoxydases et teneur en auxines de; racines du Lens. Physiol. Plant. $1,708$.

Robson, J. E. (1958). Sulphur metabolism in fungi. Radioisotopes in Scientific Research, 4 (Proc. 1st U.N.E.S.C.O. Int. Cenf. Paris, 1957), p. 28.

Robson, J. E. (1960). Autoradiog raphy of water soluble compounds in fungi. Trans. Brit. mycol. Soc. 43, 541.

Rzucidko, L., Stachow, A., Nowankowska, A. \& Kubica, J. (1950). Chemical and biological properties of the cell wall of Candida krusei, Trichophyton gypseum and Penicillium notatum. Bull. acad. pol. sci. Ser. sci. biol. 6, 15.

Tardrew, P. L. \& Johnson, M. J. (1959). The distribution of sulphur containing compounds in penicillium fermentations. J. biol. Chem. 234, 1850.

Zalokar, M. (1959). Growth and differentiation of Neurospora hyphae. Amer. J. Bot. 46, 602.

\section{EXPI,ANATION OF PLATES}

Autoradiographs of fungi reated with tritiated phenyl mercuric chloride.

\section{Prate 1}

Fig. 1. Aspergillus niger, phase-contrast L.S. hyphal tip. Cytoplasmic -SH.

Fig. 2. A. niger, phase-contrast L.S. hypha. Cytoplasmic-SH.

Fig. 3. Eremolhecium ashbeyii, autor.tdiograph T.S. hypha.

Fig. 4. E. ashbeyii, phase-contrast $\mathrm{T} \mathrm{S}$. hypha showing strong wall $-\mathrm{SH}$ reaction.

Fig. 5. E. ashbeyii, phase-contrast d fferentiating SH reaction in mature cells and young cells of hyphal branches.

Fig. 6. E. ashbeyii, autoradiograph b Id formation.

Fig. 7. E. ashbeyii, phase-contrast - ;iH reaction at site of bud formation.

Plate 2

Fig. 8. Eremothecium ashbeyii, autoradiograph. Hyphal branches.

Fig. 9. E. ashbeyii, phase-contrast - SH reactions where hyphae join.

Fig. 10. Candida albicans, autoradiograph $-\mathrm{SH}$ reaction of cell wall.

Fig. 11. C. albicans, phase-contrast F.S. budding cells.

Fig. 12. Eremothecium ashbeyii, aut, radiograph, lack of SH reaction at tip.

Fig. 13. E. ashbeyii, phase-contrast L.S. through cytoplasm.

Fig. 14. E. ashbeyii, autoradiograph L.S. wall of tip.

Fig. 15. E. ashbeyii, phase-contrast L.S. No strong -SH reaction in the wall. 


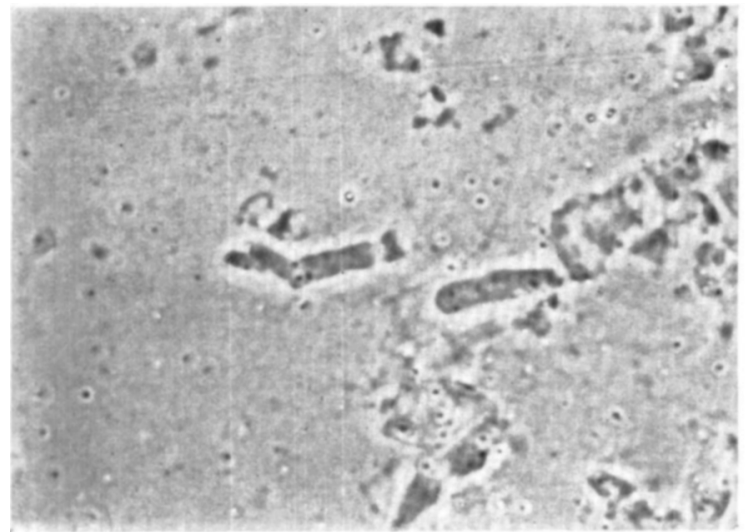

Fig. 1

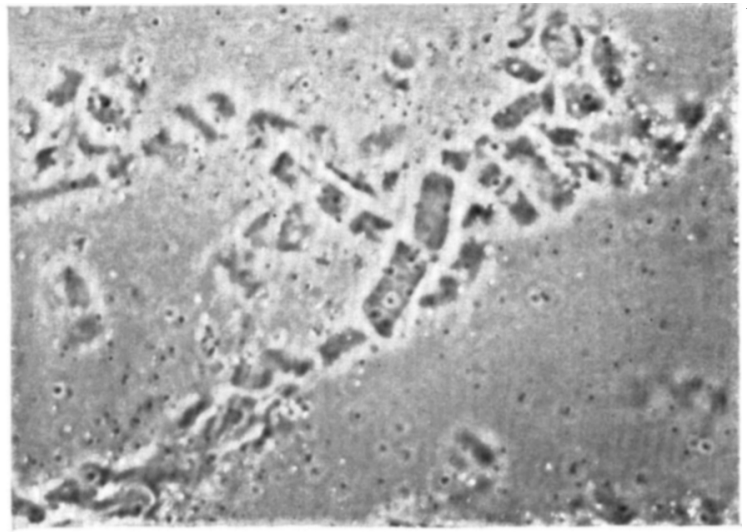

Fig. 2

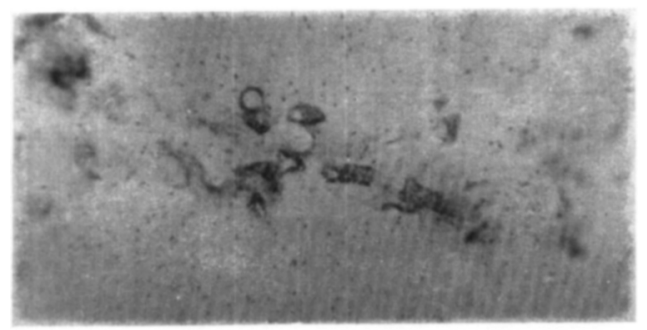

Fig. 3

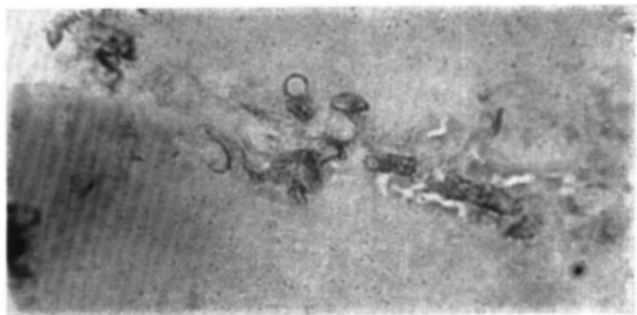

Fig. 4

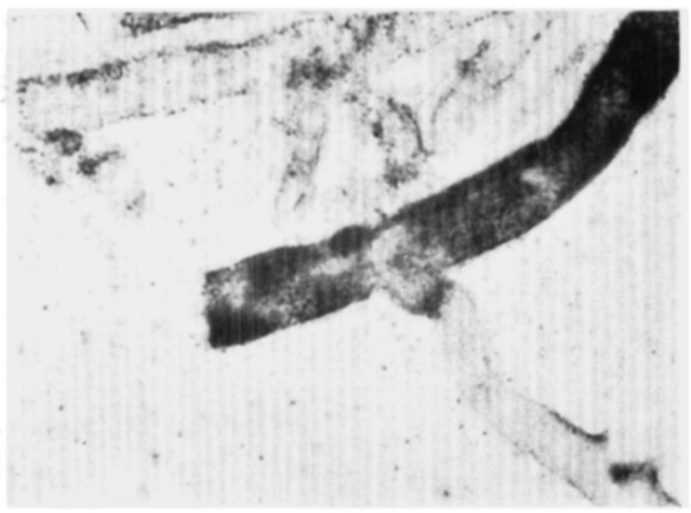

Fig. 5

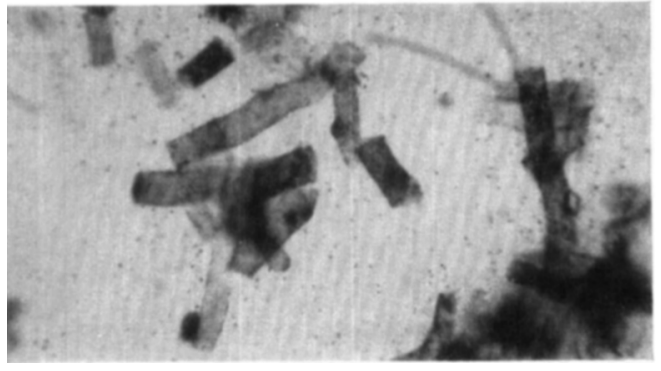

Fig. 6

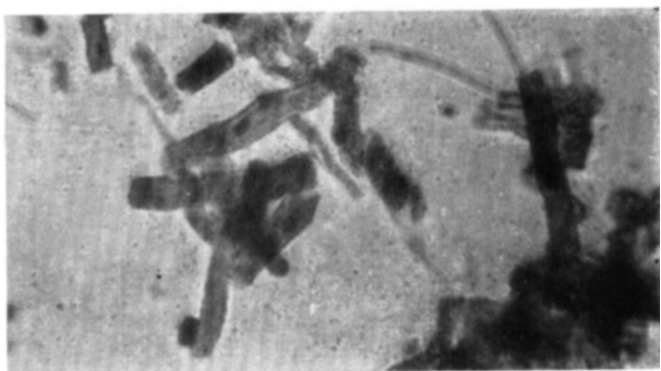

lig. 7

(Facing p. 68) 


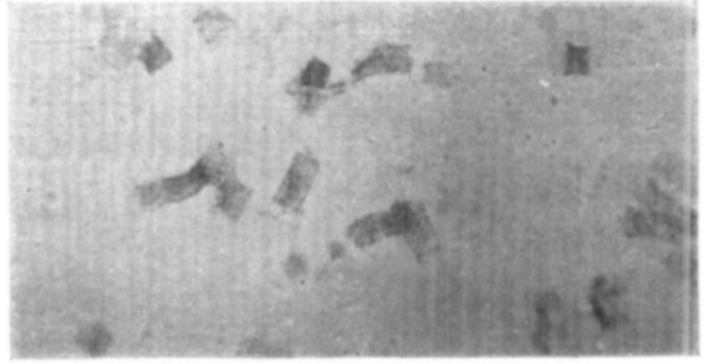

Fig. 8

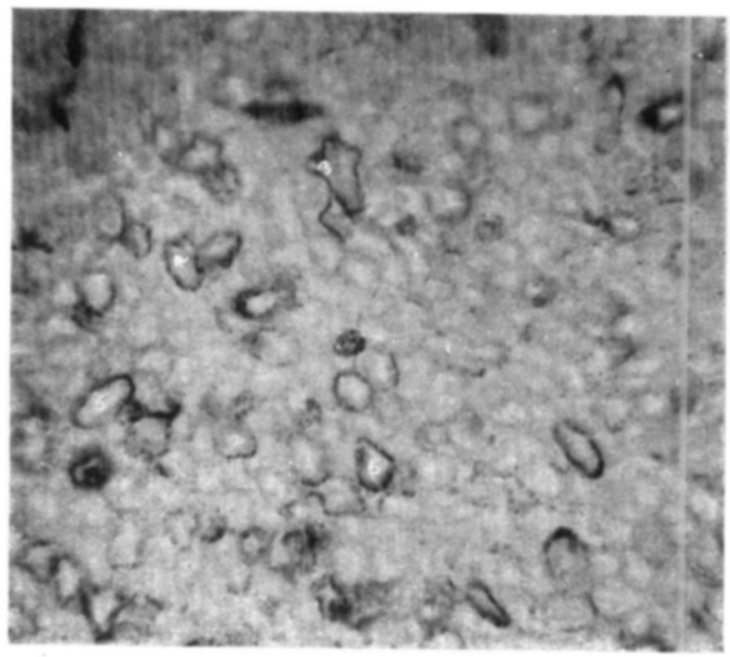

Fig. 10

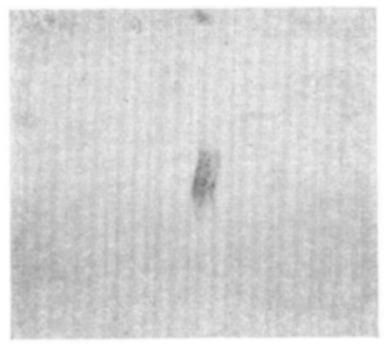

Fig. 12

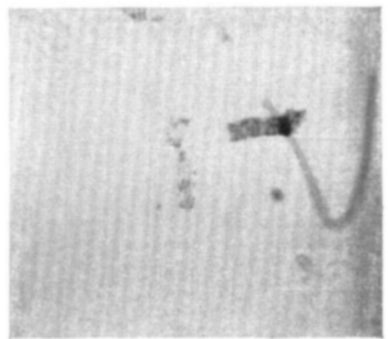

Fig. 14

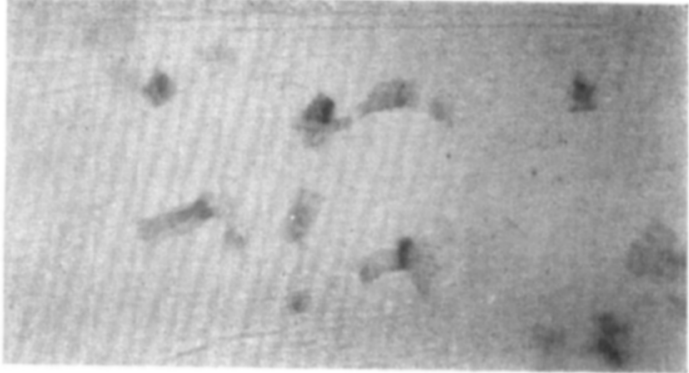

Fig. 9

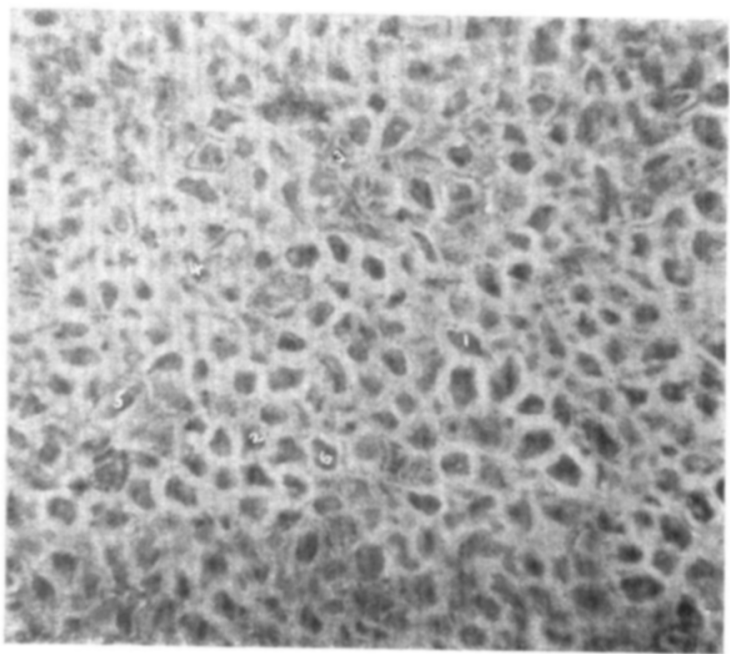

Fig. 11

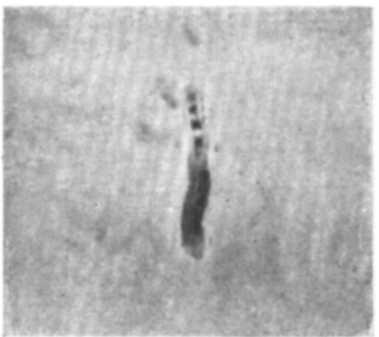

Fig. 13

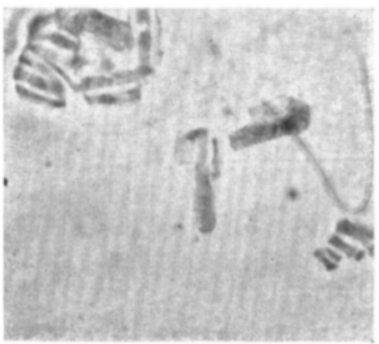

Fig. 15 